\title{
Winnaars en verliezers op de arbeidsmarkt 2000-2005
}

Citation for published version (APA):

de Grip, A., \& Dijksman, S. (2008). Winnaars en verliezers op de arbeidsmarkt 2000-2005. Tijdschrift voor Arbeidsvraagstukken, 24(1), 6-15.

Document status and date:

Published: 01/01/2008

Document Version:

Publisher's PDF, also known as Version of record

\section{Please check the document version of this publication:}

- A submitted manuscript is the version of the article upon submission and before peer-review. There can be important differences between the submitted version and the official published version of record.

People interested in the research are advised to contact the author for the final version of the publication, or visit the DOI to the publisher's website.

- The final author version and the galley proof are versions of the publication after peer review.

- The final published version features the final layout of the paper including the volume, issue and page numbers.

Link to publication

\footnotetext{
General rights rights.

- You may freely distribute the URL identifying the publication in the public portal. please follow below link for the End User Agreement:

www.umlib.nl/taverne-license

Take down policy

If you believe that this document breaches copyright please contact us at:

repository@maastrichtuniversity.nl

providing details and we will investigate your claim.
}

Copyright and moral rights for the publications made accessible in the public portal are retained by the authors and/or other copyright owners and it is a condition of accessing publications that users recognise and abide by the legal requirements associated with these

- Users may download and print one copy of any publication from the public portal for the purpose of private study or research.

- You may not further distribute the material or use it for any profit-making activity or commercial gain

If the publication is distributed under the terms of Article $25 \mathrm{fa}$ of the Dutch Copyright Act, indicated by the "Taverne" license above, 


\title{
Winnaars en verliezers op de arbeidsmarkt 2000-2005
}

\section{Reorganisatie in de laagconjunctuur}

\section{Andries de Grip en Sander Dijksman *}

\begin{abstract}
De arbeidsmarkt kent doorlopend sterke verschuivingen in de beroepenstructuur van de werkgelegenheid. In de eerste jaren van deze eeuw stonden deze werschuivingen in het teken van de reorganisaties die er in weel bedrijven plaatswonden. Daarmee is een eind gekomen aan de managementhausse die de jaren daarvoor plaatsvond. Ook is het opmerkelijk dat de voortschrijjdende ontwikkeling wan de Nederlandse kenniseconomie zich in deze recessieperiode versterkt heeft voortgezet.
\end{abstract}

Trefwoorden: groei- en krimpberoepen, ontwikkeling opleidingsniveau, reorganisatie

In een reeks eerdere artikelen hebben we een overzicht gegeven van de veranderingen in de beroepenstructuur van de Nederlandse economie sinds 1970." Deze artikelen schetsen telkens een tijdsbeeld van de "occupational winners and losers". In dit artikel zullen de verschuivingen in de beroepenstructuur in de jaren 2000-2005 in kaart worden gebracht. De werkgelegenheidsontwikkeling in deze periode vormt een schril contrast met die in de tweede helft van de jaren negentig, toen er sprake was van een ongekende hoogcomjunctuur. Tussen 2000 en 2005 nam het aantal werkenden met slechts 15.000 personen toe, tegenover een werkgelegenheidsgroei van 955.000 personem in de jaren 1995-2000.

Het ligt voor de hand dat de laagconjunctuur in de eerste jaren van deze eeuw zijn weerslag. heeft gehad op de beroepenstructuur van de werkgelegenheid. Zo staan er in de top 10 van de beroepen met de grootste werkgelegenheidswinst nog slechts twee van de sterkste groeiberoepen uit de jaren 1995-2000. Nog pregnanter is de sterke werkgelegenheidskrimp in de beroepen die de grootste klappen van de recessie hebben opgelopen. De top 10 van de beroepen met de grootste werkgelegenheidskrimp illustreert het reorganisatieproces. dat er in de Nederlandse economie heeft plaatsgewonden. Deze reorganisaties leverden. andere beroepsgroepen echter weer handen vol werk op, wat tot uiting komt in de sterke werkgelegenheidsgroei van de organisatiedeskundigen en organisatieadviseurs.

De analyses in dit artikel zijn gebaseerd op de cijfers van de Enquête Beroepsbevolking (EBB) van het $C B S$. Hierbij is uitgegaan van de door het CBS gehanteerde definitie van de werkzame beroepsbevolking (werknemers en zelfstandigen), waarbij degenen die minder dan twalf uur werken niet worden meegeteld. De beroepen zijn gecodeerd op basis van de ROA-beroepenclassificatie (ROA, 2002). In dit artikel zijn de beroepsgroepen waarin minder dan 5.000 mensen werkzaam zijn, buiten beschouwing gelaten vanwege de geringe betrouwbaarheid van de ciffers van het aantal werkenden in deze beroepsgroepen.

De verdere opzet van het artikel is als volgt. Eerst zal op dezelfde wijze als in de woorgaande artikelen een overzicht worden gegeven van de beroepsgroepen waar de werkgelegenheid in de jaren 2000-2005 absoluut of relatief gezien het sterkst is gegroeid of gekrompen.

* Andries de Grip is verbonden aan, Researchcentrum voor Onderwigs en Arbeidsmarkt (ROA), Universiteit Maastricht. Andries de Grip is ook verbonden aan. Netwert Socialle Innovatie, Universiteit Maastricht. Correspondentieadres: ROA, Universiteit Maastricht, Postbus 616, 6200 MD Mastricht, email: A.deGrip@ROA.unimaas.mL.

Sander Dijksman is verbonden aan Researchcentrum voor Onderwijs en Arbeidsmarkt (ROA), Universiteit Masstricht. 
Daarna zal worden ingegaan op het opleidingsniveau van de werkenden in de groei- en krimpberoepen. Vervolgens zal op basis van een "shift-share' analyse worden aangegeven in hoeverre het opleidingsniveau van de werkzame beroepsbevolking in de periode 2000 2005 is gestegen als gevolg van de verschuivingen in de beroepenstructuur van de economie (het structuureffect), of door de upgrading van het opleidingsniveau binnen de verschillende beroepsgroepen (het substitutie-effect). Daarbij wordt ook een vergelijking gemaakt met de ontwikkeling van het opleidingsniveau van de werkenden in de afgelopen decennia. In aansluiting hierop laten we zien in hoeverre de werkgelegenheid op de verschillende opleidingsniveaus is beïnvloed door deze structuur- en substitutie-effecten. Ten slotte geven we een overzicht wan de upgrading van het opleidingsniveau van de wrerkenden in de verschillende beroepssectoren.

\section{Groeiberoepen 2000-2005}

Tabel 1 geeft een overzicht van de beroepsgroepen waarin het aantal werkenden tussen 2000 en 2005 in absolute zin het sterkst is toegenomen. De tabel weerspiegelt evenals voorgaande keren de voortschrijdende verschuiving van de werkgelegenheid in de Nederlandse economie naar de dienstensector. Het valt op dat de beroepen in de collectieve sector weer goed vertegenwoordigd zijn onder de sterkste groeiberoepen. Dit in tegenstelling tot: de tweede helft van de jaren negentig, toen er geen enkel beroep uit de collectieve sector in de top 10 van de groeiberoepen stond. Ongetwijfeld hangt dit samen met de laagconjunctuur, waarin de minder conjunctuurgevoelige werkgelegenheid in de collectieve sector voor de bodem in de arbeidsmarkt zorgt, " terwijl de meeste beroepen in de industrie, maar ook in de zakelijke dienstverlening, veel gevoeliger zijn voor de conjuncturele ontwikkeling (zie ROA, 1999). Aan de andere kant illustreert het echter oole de structurele groei van de werkgelegenheid in de zorgberoepen vanwege de toenemende zorgvraag door de voortschrijdende medisch-technische ontwikkelingen, demografische ontwikkelingen en de ontwikkelingen in het zorggebruik (RvZ, 1999). Zo staan er drie zorgberoepen in de top 10 van de grootste occupational winners: therapeuten en verpleegkundigen (hbo-niveau), ziekenverzorgenden en verpleegkundigen (mbo-niveau) en doktersassistenten. De sterke groei vam het aantal leraren basisonderwijs illustreert de grillige invloed die het overheidsbeleid kan hebben op specifieke segmenten van de arbeidsmarkt. Zo leidde de klassenverkleining in de onderbouw van het basisonderwijs tot een wrij abrupte stijging van de vraag naar leerkrachten.

Het overheidsbeleid kan echter ook een sterke invloed hebben op de werkgelegenheid in het bedrijfsleven. Zo heeft de verruiming van de openingstijden van winkels een sterke impuls gegeven aan de vraag naar winkelpersoneel. De beroepsgroep verkopers was daardoor de grootste occupational wimner, al lag de werkgelegenheidsgroei in deze beroepsgroep al weer op een wat lager niveau dan in de tweede helft van de jaren negentig, toen het aantal. verkopers met 49.500 toenam.

De top 10 met de grootste groeiberoepen weerspiegelt ook de sterk toegenomen juridisering van de samenleving. Zo nam de werkgelegenheid voor juristen in vijf jaar tijd toe met 17.500 mensen. Maar ook de sterke werkgelegenheidsgroei van assistent-accountants en boekhouders en secretaressen is waarschijnlijk voor een belangrijk deel het gevolg van de toenemende noodzaak werantwoording af te leggen van allerhande bedrijfsprocessen, subsidieaanvragen, en dergelijke. Zeker als we beseffen dat administratieve processen in toenemende mate worden geautomatiseerd en werkzaamheden ook vaker worden uitbesteed naar landen als India, ${ }^{3}$ is de werkgelegenheidsgroei in deze beroepen zonder meer opmerkelijk te noemen.

Het is ook interessant om deze top 10 te vergelijken met de sterkste groeiberoepen uit de tweede helft van de jaren negentig. Het eerste dat daarbij opvalt, is dat de managementhausse van de afgelopen jaren kennelijk voorbij is. In de periode $1995-2000$ behoorden de 
managers (werkgelegenheidsgroei 44.000) en de bedrüjshoofden (werkgelegenheidsgroei $38.500)$ nog tot de tien sterkste groeiberoepen. Nu staan ze bij de beroepen met de grootste werkgelegenheidskrimp (zie tabel 3). Dit illustreert de 'verplatting'van de organisatiestructuur van veel bedrijwen die zich de afgelopen recessiejaren heeft voltrokken.

De ICT - beroepen blijken eveneens niet meer tot de grootste groeiberoepen te behoren. In de tweede helft van de jaren negentig stonden de systeemanalisten (werkgelegenheidsgroei 50.000 ) en de programmeurs (werkgelegenheidsgroei 39.000) nog in de top 10 van de beroepen met de grootste werkgelegenheidsgroei. De gestagneerde groei van de werkgelegenheid in deze functies is terneer opvallend als we beseffen dat ICT ers nog tot de invoering van de euro in 2002 hun finest hour kenden.

Ten slotte blijkt ook de sterke groei van de werkgelegenheid in de commerciele beroepen in de laagconjunctuur van de afgelopen jaren tot stilstand te zijn gekomen. Waarschijnlijk is dit voor een belangrijk deel toe te schrijven aan de toenemende automatisering die in callcenters plaatsvindt door middell van Voice Response Units (VRU) en Interactive Voice Response (IVR) (zie Sieben et al., 2007).

\section{Tabel I Grootste 'occupationall winners' gemeten in absolute aantallen en procentuele toemame ten opzlchte van 2000, 20010-2005}

\begin{tabular}{|c|c|c|c|}
\hline \multicolumn{2}{|c|}{ Beroepsgroep } & \multirow{2}{*}{$\frac{\text { absoluut }}{31.500}$} & \multirow{2}{*}{$\frac{\%}{11}$} \\
\hline 1 & Verkopers & & \\
\hline 2 & Leraren basisonderwijis & 31.000 & 22 \\
\hline 3 & Assistent-accountants & 23.500 & 30 \\
\hline 4 & Therapeutern en verpleegkundigen (hbo-niveau) & 22.000 & 21 \\
\hline 5 & Ziekenwerzorgenden & 21.500 & 30 \\
\hline 6 & Boekhouders en secretaresses & 18.000 & 4 \\
\hline 7 & Juristen & 17.500 & 30 \\
\hline 8 & Medewerkers sociaal-cultureel werk en personeel en arbeid & $\| 7.500$ & $\llbracket 7$ \\
\hline 9 & Interieurverzorgers & 16.500 & 10 \\
\hline 10 & Verpleeglcundigen (mbo-niveau) en doktersassistenten & 15.500 & 15 \\
\hline
\end{tabular}

Bron: EBB (CBS)

Tabel 2 geeft een overzicht wan de beroepsgroepen waar de werkgelegenheid in de jaren 2000-2005 relatief gezien het sterkst is gegroeid. In deze tabel zien we geen beroepsgroepen terug waarin de werkgelegenheid ook in absolute zin het sterkst is gegroeid. Zonder uitzondering zijn het relatief kleine beroepsgroepen waar een sterke stijging van de werkgelegenheid heeft platsgevonden. Daarbij moet worden opgemerkt dat de mogelijke meetfouten bij deze kleine beroepsgroepen vanzelfsprekend groter zijn dan bij de grotere beroepsgroe. pen, waardoor deze ranglijst minder betrouwbaar is dan de in tabel 1 gepresenteerde ranglijst van beroepsgroepen met de grootste werkgelegenheidstoename in absolute zin.

De lijst wordt aangevoerd door de hoofden saciaal-cultureel werk en personeel en arbeid. De werkgelegenheidsgroei in deze functies illustreert het toenemende belang van het Human Resources Management in vrijwel alle sectoren van de economie (zie bijv. Van Loo et al., 2006). Zoals we in tabel 1 zagen, was er ook al een sterke werkgelegenheidsgroei bij de medewerkers sociaal-cultureel werk en personeel en arbeid. De tabel laat ook duidelijk zien dat enkele beroepsgroepen sterk geprofiteerd hebben van de vele reorganisatieprocessen die in tal van bedrijven en niet-commerciële organisaties plaatsvonden. Zo steeg de werkgelegenheid voor organisatiedeskundigen in vijf jaar tijd met 12.000 arbeidsplaatsen tot 32.000 , een toename van ruim $60 \%$. Ook het aantal organisatie-adviseurs nam met 15.500 toe tot 57.000. Bij elkaar zijn dit maar liefst 90.000 mensen die het management helpen bij het veranderen van hun organisaties. De enorme groei van het organisatie-advieswerk wordt 
bevestigd door de enorme toename van het aantal organisatieadviesbureaus van $16.290 \mathrm{~m}$ het jaar 2000 naar 25.265 in 2005 (zie CBS Statline).

De relatief sterke werkgelegenheidsgroei in de beroepsgroepen sociaalwetenschappelijh medewerkers (een toename van de werkgelegenheid met 11.500 tot 23.000 arbeidsplaatsen) en sociaalwetenschappelijk onderzoekers (van 27.000 naar 40.500 axbeidsplaatsen) is eveneens opmerkelijk. Mogelijk hebben ook deze beroepsgroepen geprofiteerd van de reorganisatieprocessen die er in veel organisaties plaatswonden. Daamaast zal de werkgelegenheidsgroei in deze beroepsgroepen ongetwijfeld samenhangen met de in de jaren 2000 2005 op verschillende terreinen sterk toegenomen maatschappelijke problematiek.

Ook is er sprake van een relatief sterke werkgelegenheidsgroei van journalksten. Dit illustreert de sterke opkomst van de werkgelegenheid in de media. Daarbij gaat het niet alleen om de media die zich richten op een breder publiek, maar vooral ook om de tijdschriften, nieuwsbrieven en dergelijke die zich richten op een specifieke sector, beroepsgroep of individueel bedrijf. Hierdoor zijn er steeds meer joumalisten als freelancer werkzaam: in de jaren 2005-2006 was dat all het geval bij 29\% van de journalisten. Ten slotte laat de sterke werkgelegenheidstoename voor sportinstructeurs zien hoeveel meer aandacht we de laatste jaren hebben gekregen voor onze fitness.

Tabell 2 Grootste 'occupational winners' gemeten nat relatieve tomame ten optichte van $2000,2000-2005$

\begin{tabular}{|c|c|c|c|}
\hline \multicolumn{2}{|r|}{ Beroepsgroep } & \multirow{2}{*}{$\frac{\text { absoluut }}{9.500}$} & \multirow{2}{*}{$\frac{\%}{106}$} \\
\hline 1 & Hoofden sociaal-cultureel werk en personeel en arbeid & & \\
\hline 2 & Sociaalwetenschappelijk medewerkers & 11.500 & 105 \\
\hline 3 & Organisatiedeskundigen & 12.000 & 62 \\
\hline 4 & Brandweerlieden & 3.500 & 55 \\
\hline 5 & Sociaalwetensclinappelijk onderzoekers & $\# 3.500$ & 50 \\
\hline 6 & Ondersteunende administratieve hulpkrachten & 2.500 & 49 \\
\hline 7 & Organisatie-adviseurs & 15.500 & 37 \\
\hline 8 & Agrarische vakkrachicen & 2.500 & 36 \\
\hline 9 & Journalisten & 6.000 & 35 \\
\hline 10 & Sportinstructeurs & 3.500 & 3.4 \\
\hline
\end{tabular}

Brarn." EBE (CBS)

\section{Krimpberoepen 2000-2005}

De laagconjunctuur in de eerste jaren van deze eeuw komt vanzelfsprekend het duidelijkst naar voren in het grote aantal. beroepsgroepen met een krimpende werkgelegenheid. In 53\% van de onderscheiden beroepsgroepen was er in de periode 2000-2005 sprake van een krimpende werkgelegenheid. In de jaren 1995-2000 was dat, ondanks de sterke werkgelle genheidsgroei in deze periode, overigens ook nog bij $30 \%$ van de beroepsgroepen het geval. De werkgelegenheidskrimp in de periode 2000-2005 concentreerde zich echter oolk meer in enkele specifieke beroepsgroepen dan in de jaren 1995-2000. Tabel 3 geeft een overzicht: van de beroepsgroepen waar dle werkgelegenheid de afgelopen jaren het sterkst is gekrompen. De totale werkgelegenheidskrimp in deze beroepen bedroeg 213.000 arbeidsplaatsen, terwijl in de jaren 1995-2000 de totale werkgelegenheidskrimp bij de tien grootste occupational losers slechts 85.000 arbeidsplaatsen bedroeg.

De tabel illustreert ook duidelijk welke beroepsgroepen de grootste klappen kregen van de reorganisaties die ex plaatswonden. Het meest opvallend is de sterke werkgelegenheidskrimp in de managementberoepen. Maar liefst vijf van de tien beroepsgroepen met het grootste werkgelegenheidsverlies hebben betrekking op leidinggevende functies. ${ }^{4}$ Zo nam het atntal werkenden in de beroepsgroep managers in vijf jaar tijd met 26.500 af en was er eveneens 
een flinke werkgelegenheids krimp bij de beroepsgroepen leidinggevenden, bedrijtshoofden, agrarische bedriffshoofden en bedrijfshoofden horeca. In totall daalde de werkgelegenheid in deze vijf beroepsgroepen met 97.000 arbeidsplatsen. Deze werkgelegenheidskrimp laat. zien dat het reorganisatieproces in veel bedrijven betrekking had op een verplatting van de organisaties, waarbij eén of meer managementlagen zijn geschrapt. Daarnaast is de daling wan het aantal bedriffshoofden horeca en agraxische bedrijfshoofden en de daling van het aantal winkeliers waarschijnlijk het gevolg van de bedrijfssluitingen die zich in een laagconjunctuur plaatsvinden. Deze bedrijfssluitingen vormen een onderdeel wan de concentratieprocessen die zich in deze sectoren waax veel midden en kleinbedrijf actief is, hebben voorgedaan.

Ook heeft er een sterke daling van de werkgelegenheid plaatsgevonden bij de commerciële medewerkers; een beroepsgroep die in de jaren 1995-2000 nog in de top 10 van de grootste groeiberoepen stond. Zoals gezegd, zal dit voor een belangrijk deel het gevolg zijn van de sterk toegenomen automatisering in de callcentersector. De sterke werkgelegenheidsdalingen bij de beroepsgroepen chauffeurs en metaalarbeiders illustreren de saneringsprocessen in de vervoerssector en de metaalindustrie, waarbij ook een deel wan de werkgelegenheid naar Oost-Europese landen met een lager loonpeil is verplaatst.

Tabel 3 Grootste 'occupational losers' gemeten in absolute aantallen en procentuele afname ten opzichte van 2000, 2000-2005

\begin{tabular}{|c|c|c|c|}
\hline \multicolumn{2}{|c|}{ Beroepsigroep } & \multirow{2}{*}{$\begin{array}{r}\text { absolumut } \\
-29.000\end{array}$} & \multirow{2}{*}{$\begin{array}{r}\% \\
-13\end{array}$} \\
\hline 1 & Cornmercieel medewerkers & & \\
\hline 2 & Agrarische arbeiders & -27.500 & .25 \\
\hline 3 & Managers & -26.500 & -24 \\
\hline 4 & Chauffeurs: & -20.500 & -9 \\
\hline 5 & Metaalarbeider"s & $-20,000$ & -23 \\
\hline 6 & Leidlinggevenden & -19.000 & -314 \\
\hline 7 & Bedrijfshoofden & -19.000 & -32 \\
\hline 8 & Winkeliers & .19 .000 & .14 \\
\hline 9 & Agrarische bedrijifishoofden & -17.000 & .16 \\
\hline 10 & Bedrijfshoofden horeca & -15.000 & -30 \\
\hline
\end{tabular}

Bron: EBB (CBS)

\section{Het opleidingsniveau van de groei- en krimpberoepen}

De eerdere 'winnaars en verliezers'-artikelen lieten all zien dat de verschuivingen in de beroepenstructuur een beeld geven van de wijze watarop de kenniseconomie zich in Nederland ontwikkelt. Het gemiddelde opleidingsniveau van de werkenden in de meeste groeiberoepen bleek telkens hoger te zijn dan het opleidingsniveau van de werkenden in de beroepen met een krimpende werkgelegenheid. De tabellen $4 \mathrm{a}$, $4 \mathrm{~b}$ en 5 laten zien in hoeverre dat ook in de jaren 2000-2005 het geval is geweest. On een vergelij).king te kunnen maken met de ontwikkelingen in de voorgaande perioden wordt het gemiddelde opleidingsniveau (GON) op dezelfde wijze berekend als in de woorgaande artikelen. Daarbij is aan de opleidingsachtergronden van de werkenden in een bepaalde beroepsgroep het aantal opleidingsjaren na het basisonderwijs toegerekend. Bij het vaststellen van het GON voor een beroepsgroep wordt zowel de gevolgde initiele opleiding als de later gevolgde postinitiële 'opscholing' wan de werkenden in het beroep meegenomen (zie De Grip \& Dijksman, 2004). 
Tabel 4a Gemiddeld en modaall opleidingsniveau van de absolurut sterkst toegenomen beroepsgroepen, 2000-2005

\begin{tabular}{|c|c|c|c|c|}
\hline \multicolumn{2}{|c|}{ Bieroepsgrolep } & \multirow{2}{*}{$\begin{array}{r}\text { GON } \\
2000 \\
4,3\end{array}$} & \multirow{2}{*}{$\begin{array}{r}60 N \\
2005 \\
4,8\end{array}$} & \multirow{2}{*}{$\begin{array}{l}M 0 \mathrm{~N} \\
2000 \\
\text { mbo }\end{array}$} \\
\hline $\mathrm{T}$ & Verkopers & & & \\
\hline 2 & Leraren basisonderwilis & 8,8 & 8,9 & hao \\
\hline 3 & Assistent-accountants & 7,9 & 87 & hbo \\
\hline 4 & Therapetiten en verpleegkundigen (hbo-niveau) & 8,3 & 8,7 & hbo \\
\hline 5 & Ziekenverzorgenden & 6,2 & 6.4 & mbo \\
\hline 6 & Boelikhouders en secretaresses & 6.1 & 6.4 & mbo \\
\hline 7 & Juristen & 10,9 & $\left\|I_{n}\right\|$ & wo \\
\hline 8 & Medewerkers sociaal-cultureel werk en personee an arbeid & 8,9 & 9,2 & habo \\
\hline 9 & Interieurwerzorgers & 3,1 & 3.7 & vimbo \\
\hline 10 & Verpleegkundigen (mbo-niveat) en dokcersassistenten & 6,1 & 6,2 & mbo \\
\hline
\end{tabular}

Bron: CBSIROA

Tabel 4b Gemiddeld en modaal opleidingsniweau van de relatief sterkst toegenomen beroepsgroepen, 2000-2005

\begin{tabular}{|c|c|c|c|c|}
\hline \multicolumn{2}{|c|}{ Beroepsgroiep } & \multirow{2}{*}{$\begin{array}{r}\text { GON } \\
2000 \\
11.9\end{array}$} & \multirow{2}{*}{$\begin{array}{r}\text { GON } \\
2005 \\
12,0\end{array}$} & \multirow{2}{*}{$\begin{array}{r}\text { MON } \\
2000 \\
\text { Wo }\end{array}$} \\
\hline 1 & Hoofden sociaall-cultureel werk en personeel en arbeid & & & \\
\hline 2 & Sociaalwetenschappelijk medewerkers & 8,3 & 8,2 & hbo \\
\hline 3 & Organisatiedeskundigen & $\| 1,9$ & 11.9 & wo \\
\hline 4 & Brandweerlieden & 5.7 & 5.7 & mbo \\
\hline 5 & Sociaalwetenschappelijk onderzoekers & $\| 1.7$ & 11.9 & wo \\
\hline 6 & Ondersteunende administratieve hulpkrachten & 6.5 & 5,3 & mibo \\
\hline 7 & Organisatie-adviseurs & 8,5 & 8.8 & ntoo \\
\hline 8 & Agrarische vakkrachtem: & 5,8 & 5,9 & monbo \\
\hline 9 & Journalisten & 8,3 & 8.7 & hibo \\
\hline 10 & Sportinstructeurs & 6,4 & 6,4 & mbo \\
\hline
\end{tabular}

Bron: CBSIROA

Tabel 4a en tabel $4 \mathrm{~b}$ geven een overzicht van het gemiddeld opleidingsniveau (GON) en modaal opleidingsniveau (MON) van de beroepsgroepen die tussen 2000-2005 absoluut of relatief gezien het sterkst groeiden. Uit de tabellen blijkt dat veel van de beroepsgroepen met de sterkste werkgelegenheidsgroei werkgelegenheid bieden aan hoger opgeleiden. Bij vijf van de tien beroepen met de sterkste groei in absolute zin ligt het GON op hbo- of zelfs wo-niveau. In de jaren 1995-2000 was dat nog slechts bij twee van de tien beroepen het geval. Bij deze groeiberoepen voor hoger opgeleiden gaat het zowel om beroepen die met name voorkomen in de publieke sector, als om beroepen uit de commerciêle dienstverlening. Bij vier andere groeiberoepen ligt het modale opleidingsniveau op mbo-niveau. Ook hier gaat het weer om zowel beroepen uit de commerciële als de niet-commerciêle dienstverlening. De interieurverzorgers zijn het enige groeiberoep waar de meeste werkenden slechts een vmbo-diploma hebben. Het gemiddelde opleidingsniveau van de werkenden blijkt overigens in alle tien groeiberoepen tussen 2000 en 2005 te zijn gestegen. Deze toenarne van het GON was het hoogst bij de assistent accountants en de interieurverzorgers.

Tabel. $4 \mathrm{~b}$ laat zien dat de top 10 van de beroepen met relatief gezien de grootste werkgelegenheidsgroei nog sterker gedomineerd wordt door de hogere beroepen. Bij zeven van de tien beroepen ligt het modale opleidingsniveau op hbo- of wo-niveau; bij de overige drie beroepen op mbo-niveau. Het is opmerkelijk dat er bij de beroepen met relatief gezien de sterkste werkgelegenheidsgroei veel minder vaak sprake is van een toename van het GON dan bij de beroepen in tabel 4a. 
Tabel 5 Giemilddeld en modlaal opleidingsniveau van de absoluut sterkst afgenomen beroepsgroepen, 2000-2005

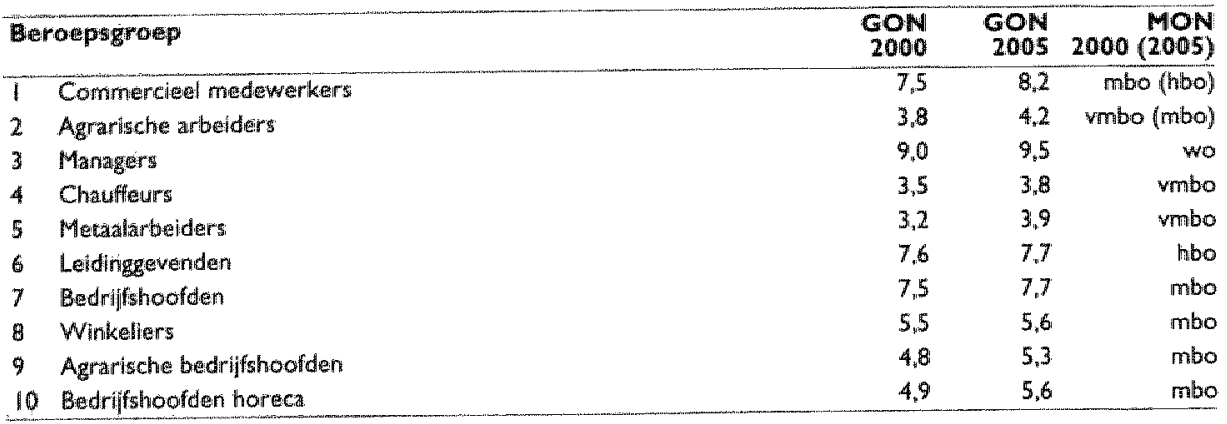

Broni: CBS/ROA

Daarentegen werken er in drie van de tien beroepen met de grootste werkgelegenheidskrimp veel vmbo'ers. Het gaat hier om de agrarische arbeiders, chauffeurs en metaalarbeiders. Bij de agrarische arbeiders is het MON tussen 2000 en 2005 overigens verschoven maar het mbo-niweau. De beroepsgroepen managers en leidinggevenden zijn de enige krimpberoepen woor de hoger opgeleiden. De werkgelegenheidskrimp in de managementfuncties heeft dan ook voor een groot deel plaatsgevonden in de middenkaderfuncties. Zo heeft in drie van de vijf managementberoepen met een sterk gekrompen werkgelegenheid de grootste groep werkenden een mbo-opleiding (bedrijfshoofden, agrarische bedrijfshoofdern en bedrijfshoofden horeca).

\section{Verschuivingen in de opleidingenstructuur}

De upgrading van het functieniveau van de werkgelegenheid is echter niet alleen het gevolg van de verschuivingen in de beroepenstructuur. In tabel 6 wordt door middel van een shift share analyse aangegeven in hoeverre de upgrading van het gemiddelde opleidingsniveau van de werkzame beroepsbevolking (GON) is toe te schrijven aan de verschuivingen in de beroepenstructuur (het structuureffect), of het gevolg is geweest van veranderingen in het opleidingsniveau van de werkenden binnen de verschillende beroepsgroepen (het substitutieeffect) Daarmaast is er nog sprake van een (klein) interactie-effect, dat de gevolgen van simultane verschuivingen in de beroepenstructuur aangeeft. ${ }^{5}$

Tabel 6 Verandering van het gemiddelde opleidingsniveau (GON), opgedeeld in een structuur- en substilutilemeffect, $1981-2005$

\begin{tabular}{lrrrrr} 
Puriode & $\begin{array}{r}\text { GON } \\
\text { beginjaar }\end{array}$ & $\begin{array}{r}\text { GON } \\
\text { eindjaar }\end{array}$ & Totaleffect & $\begin{array}{r}\text { Structuur- } \\
\text { effect }\end{array}$ & $\begin{array}{r}\text { Substitutie- } \\
\text { effect }\end{array}$ \\
$1981-1985^{*}$ & 4,58 & 5,05 & 0,47 & 0,15 & 0,33 \\
$1985-1990^{*}$ & 5,05 & 5,46 & 0,41 & 0,17 & 0,25 \\
$1990-1995$ & 5,46 & 5,85 & 0,39 & 0,12 & 0,28 \\
1995.2000 & 5,85 & 6,05 & 0,20 & 0,11 & 0,09 \\
2000.2005 & 6,05 & 6,45 & 0,40 & 0,08 & 0,32 \\
\hline
\end{tabular}

In de periode 1981-1990 is er gebruikgemalkt wan een andere codering van de beroepsgroepen

Bron: CBSIROA

Tabel 6 laat in de eerste plaats zien dat het gemiddelde opleidingsniveau van de werkzame bevolking in de periode $2000-2005$ veel sterker is toegenomen dan in de tweede helft van de jaren megentig. Met een toename van 0,4 opleidingsjaar lag de upgrading van het opleidingsniveau weer op het niveau van voor 1995. Dit wijst erop dat de afremming van het upgradingsproces in de periode 1995-2000 het gevolg is geweest van een tekortschietend aanbod van hoger en middelbaar opgeleiden, waardoor lager opgeleiden meer kansen kregen 
op de arbeidsmarkt. Dit verklaart ook waarom in de afgelopen recessieperiode de werklloos" heid onder de laag opgeleiden het sterkst is toegenomen. Zo steeg de werkloosheid onder mensen met alleen basisonderwijs tussen 2000 en 2005 van $7,5 \%$ naar $13,3 \%$ en bij de vmbo'ers van $4,2 \%$ naar $8,5 \%$, terwijl de werkloosheid onder hbo'ers slechts toenam van $2,7 \%$ naar $3,8 \%$.

Uit de shift-share analyse blijkt dat de upgrading van het opleidingsniveau van de werkenden in de jaren 2000-2005 veel minder het gevolg is geweest van de verschuivingen in de beroepenstructuur dan in het verleden. Daarentegen was er sprake van een sterke toename van het upgradingseffect binnen de verschillende beroepsgroepen. Tabel 7 laat zien dat met name de hoger opgeleiden (hbo en wo) geprofiteerd hebben van dit substitutie-effect, ten koste van de lager opgeleiden (vmbo en lagex). De hoger opgeleiden zijn ook de enigen die substantieel geprofiteerd hebben van de verschuivingen in de beroepenstructuur. ${ }^{\circ} \mathrm{Op}$ bijna alle andere opleidingsniveaus was er sprake van een negatief structuureffect. Het hoge substitutie-effect bij de h.bo'ers wijst erop dat de in de jaren negentig ingezette 'hboisering' van de valkarbeid zich in de jaren 2000-2005 sterk heeft voortgezet. Deze hbo-isering is in lijn met de gesignaleerde ontwikkeling in de richting, van plattere organisatiestructuren, waarin 'professionals' - al of niet in teamverband - een relatief grote autonomie hebben (zie bijv. Ichniowski \& Shaw, 2003).

Tabel 7 Veranderingen in het werkgelegenheidsaandeel naar opleidingsniveau, opgedleelld in eein structuuir- en substitutie-effiect (iin procenten), 2000-2005

\begin{tabular}{|c|c|c|c|}
\hline Opleidingsniveau & Totaaleffeet & Structuureffect & Substitutie-effect \\
\hline Basisonderwilis & $-2,10$ & $-0,22$ & $-1,97$ \\
\hline Vmbo Theorie & $-0,92$ & $.0,11$ & $-0,85$ \\
\hline Vmbo & $-1,39$ & $-0,60$ & $-0,92$ \\
\hline Havolvwo & 0,35 & 0,06 & 0,31 \\
\hline Mbo & $-0,36$ & $-0,25$ & $-0,04$ \\
\hline Hbo & 2,49 & 0,46 & 1,90 \\
\hline Wo & 1,94 & 0,43 & 11.45 \\
\hline
\end{tabular}

Bron: CBS/ROA

Tabel 8 Verandering in het gemiddelde opleidingsniweau (GON), verbijzonderd naair beroepssector opgedeeld in eren structuuir-en substitutie-effect, 2000-2005.

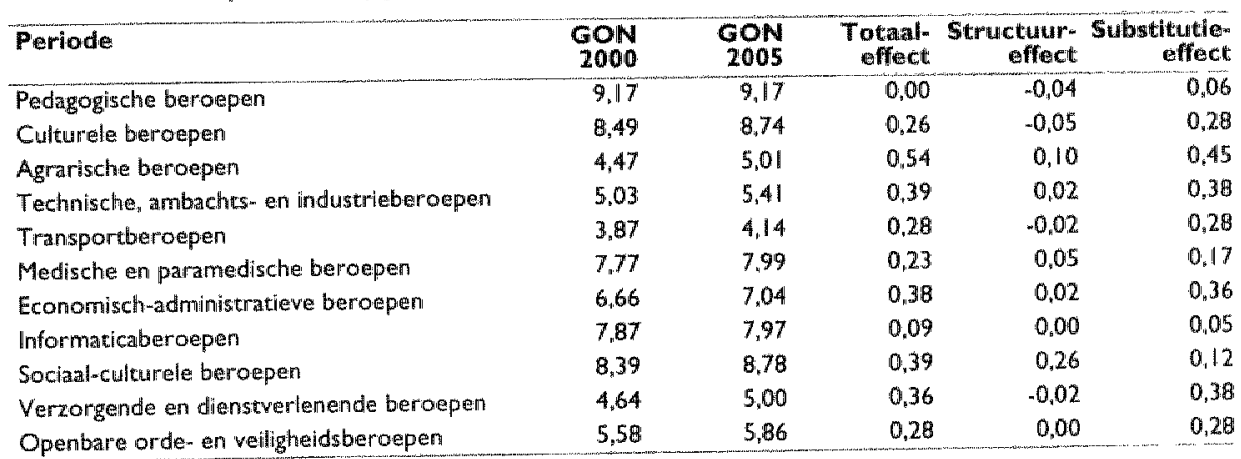

BRON: CBSIROA

De sterke upgrading van de opleidingsstructuur van de werkgelegernheid in de eerste jaren van deze eeuw roept de vraag op in welke beroepssectoren deze stijging het meest manifest is geweest. Tabel 8 laat zien dat de upgrading het sterkst is in de agrarische, technische, sociaal-culturele, economisch-administratieve en verzorgende beroepen. Met uitzondering van de sociaal-culturele beroepen gaat het daarbij wooral om een toename van het gemiddelde 
opleidingsniveau binnen de werschillende bexoepsgroepen. Alleen in de pedagogische beroepen (de leraren) heeft ex geen enkele upgrading platsgevonden. Dit illustreert de relatieve verzwatking wan de positie van deze beroepssector in de huidige kemniseconomie ten opzichte van de andere beroepen. Opvallend is ook het achterblijven van de informaticaberoepen. Ook hier lijlkt de upgrading van de opleidingseisen te stagneren.

\section{Besluit}

In dit artikel hebben we een beeld geschetst van de belangrijkste verschuivingen in de beroepenstructuur van de werkgelegenheid en de toename van het opleidingsmiveau van de werkenden in de faren 2000-2005. De verschuivingen in de beroepenstructurur laten ook zien welke beroepsgroepen de klappen hebben opgevangen van de reorganisatieprocessen die zich in deze recessieperiode hebben woorgedaan. Wat daarbij het meest in het oog springt, is dat de enome groei van de managementfuncties in de jaren tachtig en negentig van de vorige eeuw in de jaren 2000-2005 geheel tot stilstand is gekomen door de verplatting wan veel organisaties. De weer sterk toegenomen upgrading van het opleidingsniveau van de werkenden laat duidelijk zien dat de voortschrijdende ontwikkeling van de Nederlandse kenniseconomie zich in deze periode van laagconjuncturur versterkt heeft doorgezet.

\section{Noten}

1 Deze artikelen hebben achtereenvolgens betrekking op de jaren zeventig (De Grip, 1986) en de perioden 1981-1985 (De Grip, 1987), 1985-1990 (De Grip \& Delkker, 1993), 1990-1996 (De Grip \& Van Loo, 2000) en 1995-2000 (De Grip \& Dijksman, 2004). De Grip (2001) geeft een overzicht: wan de ontwikkelingen in de jaren 1970-1995.

2 In het Arbeidsmarktinformatiesysteem van het $\mathrm{ROA}$, waarvan de belangrijkste uitkomsten gepubliceerd worden in thet tweejaarlijkse rapport De arbeidsmarkt naar opleiding en beroep (zie bijw. ROA, 2007) wordt de conjunctururgevoeligheid van de werkgelegenheid in de collectieve sectorberoepen met de sterkst gegroeide werkgelegenheid als volgt getypeerd: Leraar basisonderwijs: laag; Therapeuten en verpleegkundigen: erg laag; Ziekenverzorgenden: gemiddeld; Verpleegkundigen en doktersassüstenten: gemiddeld.

3 'Bedrijven als KLM "CMG, Atos Origin, Baan, Philips, Shell, Unilever, Pink Roccade, Getronics, ING zijn reeds lange tijd actief in India. De trend is dat het aantal bedrijwen dat uitbesteedt naar India snel toeneemt en met name het aantal MKB bedrijven dat de weg naar India windt in snel tempo zall groeien." ‘www.easternenterprise.com/html/india.htm? "Zo werken er woor CapGenini immiddels 14.000 mensen in India (Trouw, 12 juni 2007).

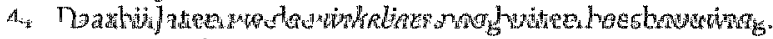

5 Deze erg kleine interactie-effecten hebben we niet in de tabellen 6-8 opgenomen.

6 Ook bij de havio'ers/vwo"ers is er sprake van een licht positief structureffect. Overigens zijn dit in de praktijk meestal mensen die hun hbo- of wo-opleiding niet hebben voltooid.

\section{Literatuur}

Grip, A. de (1986). Winnaars en verliezers op de arbeidsmarkt in de jaren '70'. Tijdschrift voor Arbeidsweragstukken, 2, 41-51.

Grip, A. de (1987). Winnaars en verliezers op de arbeidsmarkt 1981-1985. Tijdschrift voor Arbeidsurangstukken, 3, 61-69.

Grip, A. de (2001). Dynamiek op de arbeidsmarkt en de employability van werkenden. Tijdschrift voor Arbeidsuraggstukken, 17, 213-221.

Grip, A. de \& Dekker, R. (1993). Wimaars en verliezers op de arbeidsmarkt 1985-1990. Tijdschrift woor Arbeidsuraagstukken, 9, 220-229.

Grip, A. de \& Dijksman, S. (2004). Winnaars en verliezers op de arbeidsmarkt 1995-2000. Tijdschrift voor Arbeidsvraagstukken, 20, 169-181.

Grip, A. de \& Loo, J. wan (2000). Winnaars en verliezers op de arbeidsmarkt 1990-1995. Tijdschrift poor Arbeidswraggstukken, 16, 6-17.

Ichniowski, C. \& Shaw, K. (2003). Beyond incentive pay: Insiders' estimates of the value of complementary human resource mamagement practices. Journal of Economic Perspectives, $17,155-180$.

Loo, J. van, Grip, A. de \& Lintjens, E. (2006). Arbeidsmarktmonitor Metalektra 2005, ROA-R-2006/ 5. Maastricht: ROA. 
ROA (1999). De arbeidsmarkt naar opleiding en beroep tot 2004. Statistische bijlage, ROA-R-1999/ 8B. Maastricht: ROA.

ROA (2002). ROA-classificatiegids 2002. Maastricht: ROA.

ROA (2007). De arbeidsmarkt naar opleiding en beroep tot 2012, ROA-R-2007/4. Maastricht: ROA.

RvZ (1999). Zargarbeid in de toekomst. Gevolgen van demografische ontwikkelingen voor de zorg. Den Haag/Zoetermeer: RvZ.

Sieben, I., Grip, A. de, Longen, J. \& Sørensen, O. (2007). Technology, Sellection and Training in Call centers, ROA-RM-2007/4. Maastricht: ROA. 